\title{
State Sponsorship: An Impediment to the Global Fight against Terrorism
}

\author{
Dr Michael Hanson* \\ https://doi.org/10.21827/GroJIL.7.2.132-144
}

\section{Keywords:}

TERRORISM; STATE TERRORISM; STATE-SPONSORED TERRORISM; GLOBAL FIGHT; CIVILIAN; NON-COMBATANT AND LEGAL SETUPS

\begin{abstract}
Following the terrorist attack on the United States of America on 11 September 2001, global efforts against terrorism have increased. Notwithstanding these efforts, terrorist attacks continue across the globe amidst accusations that some States provide support for terrorists. This work examines the State sponsorship of terrorist groups in light of the global fight against terrorism. The methodology used here is doctrinal. This work finds that the continuous provision of resources to terrorist groups by some States against the dictates of relevant existing international legal setups operates as an impediment to the global fight against terrorism. It concludes that cutting off State support for terrorists remains the sine qua non for achieving success in the global war against terror. To do this requires the strengthening of international laws on terrorism, increasing diplomatic relations to expose involved States, imposing and enforcing strong sanctions against supporting States, reduction of such States' meddling in activities of other countries, increased assistance to failed States and decreased assistance to involved States.
\end{abstract}

\section{Introduction}

The earliest cases of what could be considered as acts of terrorism were perpetrated by the Jewish Sicarii (dagger men) and the Zealot group, over 2000 years ago in Rome. ${ }^{1}$ This was followed by the assassins in Persia (now Iran and Syria) between 1090 and $1272 .{ }^{2}$ In spite of the acts of these groups, it was only during the French Revolution of 1789-1799 that the phrase 'State terrorism', or 'State-sponsored terrorism', was used to identify the acts of violence carried out by the ruling Jacobins to intimidate the regime's enemies and compel obedience to the State. ${ }^{3}$ During this period, the term 'terrorism' was associated with State terror and the reign of terror in France until the middle of the $19^{\text {th }}$ century, when the term had also began to

* Dr Michael D Hanson, LLB, BL, LLM, PhD, Lecturer, Department of International Law and Jurisprudence, Faculty of Law, University of Uyo, Uyo, Nigeria. Email: michaelhanson2007@yahoo.com. GSM: 08028442301 .

1 Christian Akani, '2011 Terrorism Act in Nigeria: Prospects and Problems' (2013) 2(8) International Journal of Arts and Humanities 218, 218.

2 Brigitte L Nacos, Terrorism and Counterterrorism (4th ${ }^{\text {th }}$ ed, Pearson Education 2012) 35.

3 Ali S Yusuf Bagaji and others, 'Boko Haram and the Recurring Bomb Attacks in Nigeria: Attempt to Impose Religious Ideology through Terrorism?' (2012) 8(1) Cross-cultural Communication 33, 37. See Bruce Hoffman, Inside Terrorism (Columbia University Press 1998) 33, cited in Nacos (n 2) 1. 
be associated with non-governmental groups. ${ }^{4}$ However, in spite of its long existence and prevalence, terrorism remains a complex term with no universally acceptable legally binding or criminal law definition. ${ }^{5}$ This arises from the perception given to it from different people and groups all over the world. Whereas people or groups who disagree with the course of those who commit political violence against civilians or non-combatants condemn them as terrorists, those who share or sympathise with the grievances of the perpetrators consider them as freedom fighters, militants, revolutionaries, rebels, warriors and so on. ${ }^{6}$ This is why it is often said that 'one man's terrorist is another man's freedom fighter'. ${ }^{7}$ Accordingly, many individuals and groups, as well as some States, view these individuals or groups not as terrorists but as freedom fighters, militants, rebels or nationalists. This perception is part of what makes some of these States provide support for these terrorists, which assists them in the perpetration and perpetuation of terrorism across the world. These are the States involved in the sponsorship of terrorism.

This work is divided into seven parts. Part one is the introduction. In part two, an exposition of what constitutes State terrorism is undertaken, in order to elucidate the existing controversies with regards to the recognition of States as perpetrators of terrorism. Part three analyses State-sponsored terrorism and identifies States labelled as sponsors and the vicissitudes associated with such labels. Part four examines extant international legal instruments used in combating terrorism. Part five provides analyses on resource mobilisation for terrorist groups. It shows the existence of a connection between the availability of resources as a necessary prerequisite for the emergence, existence and persistence of terrorist groups and their activities. Part recommends measures that could be used in addressing States' involvement in the sponsorship of terrorist groups around the world. Part seven concludes.

\section{State Terrorism}

Although disagreement over the definition of terrorism continues to dominate contemporary research, it generally refers only to those unlawful, violent and brutal acts which are intended to create fear or terror, for religious, political, economic, social or ideological objectives, and deliberately target or disregard the safety of non-combatants. While the modern usage of the word 'terrorism' is associated with political violence perpetrated by insurgents, having civilians as the target, some scholars have accommodated the concept of State terrorism and State-sponsored terrorism in their interpretation. Thus, State terrorism is considered to refer to acts of terrorism committed by a State against foreign targets or against its own people. ${ }^{8}$ According to Gus Martins, State terrorism is terrorism committed by the government or quasigovernmental agencies and their personnel against perceived threats which could be directed against both domestic and foreign targets. ${ }^{9}$ Noam Chomsky defines State terrorism to mean

4 Chris Millington, 'Terrorism in France' (History Today, 8 January 2015) <historytoday.com/terrorismfrance $>$ accessed 15 December 2019.

5 Manzoor Khan Afridi, 'Military Operation as a Response to Terrorism: A Case Study of Malakand Division, Pakistan' (2014) 5(20) Mediterranean Journal of Social Sciences 2001.

6 Nacos (n 2) 11.

7 Walter Laqueur, The Age of Terrorism (Little, Brown and Company 1987) 302; see also Boaz Ganor, 'Defining Terrorism: Is One Man's Terrorist Another Man's Freedom Fighter?' (2002) 3(4) Police Practice and Research 287, 287.

Anthony Aust, Handbook on International Law ( $2^{\text {nd }}$ ed, Cambridge University Press 2010) 265.

9 Gus Martins, Understanding Terrorism: Challenges, Perspectives and Issues (Sage 2006) 111. 
terrorism practiced by States (or governments) and their agents and allies. ${ }^{10}$ State terrorism, therefore, comes to focus when terrorism is described in terms of the violent nature of the act against civilians, without considering the perpetrators. ${ }^{11}$ Thus, violent acts perpetrated by governments and their agents against civilians and non-combatants (more often than not, secretly) are usually referred to as State terror or State terrorism. ${ }^{12}$ Where a State openly or secretly performs acts of terrorism, or supports the acts performed by a group, or acquiesces in their performance of the acts, such a State is held to be involved in State terrorism. ${ }^{13}$ It has been maintained that governments and their agents can practice terrorism in their countries or abroad and that the use of such violence is usually concealed to avoid public attribution of responsibility. ${ }^{14}$ Therefore, aside from revolutionaries and nationalists, evidence abounds that terrorism has been used, in the recent past, by governments as an instrument to maintain State control. ${ }^{15}$ Moreover, when used by the State against civilians and non-combatants, terrorism can be, and has been in many instances, equally as brutal as the actions of non-State actors, or even far deadlier. ${ }^{16}$

State terror, or State terrorism, has been identified in Germany, Italy and France. ${ }^{17}$ In Germany, beginning in the 1920s, violent groups organised under Adolf Hitler attacked political opponents within Germany. These acts of terrorism perpetrated by Hitler and his groups brought him to power in 1933 and beyond. The state of violence during Hitler's years resulted in the death of more than ten million innocent civilians at the hands of his government. ${ }^{18}$ In Italy, the reign of Benito Mussolini with his fascist regime also witnessed the use of State apparatus to commit violence against civilians. ${ }^{19}$ There was also unspeakable State terror in the then Soviet Union during the reign of Joseph Stalin. During this time, millions of civilians were tortured and killed by the government. In recent times, some States continue to use violence against innocent civilians, which has led to the death of millions within their borders. A justification sometimes employed by these States for such acts is that they are fighting rebellions, terrorists or militants. ${ }^{20}$ However, in so doing, no line is drawn between innocent civilians, who are involved in genuine protests, and terrorists, rebels and militants, who have taken up arms against the State for their selfish criminal or political goals. It has been observed that no case of non-State political violence is ever close to the enormity of the atrocities committed by States against their citizens. ${ }^{21}$

10 Noam Chomsky, 'What Anthropologist Should Know About the Concept of Terrorism' (2002) 18(2) Anthropology Today.

11 ibid.

12 Nacos (n 2) 30.

13 G Lopez and M Stohl, Terrible Beyond Endurance?: The Foreign Policy of State Terrorism (Greenwood Press 1988) 207-208.

14 M Crenshaw, 'How Terrorists Think: What Psychology Can Contribute to Understanding Terrorism' in L Howard (ed), Terrorism, Roots, Impact, Responses (Praeger 1992) 4.

15 IA Oche, 'Africa And The Resurgence of Terrorism- Revisiting The Fundamentals' (2014) 2(2) Global Journal of Arts Humanities and Social Sciences 1, 2.

16 Nacos (n 2) 30.

17 ibid.

18 ibid.

19 ibid

20 ibid.

21 ibid 31. 
According to RJ Rummel, cited by BL Nacos, State terrorism, or State terror, is not within the definitional concept of terrorism..$^{22}$ Although acts which constitute terrorism are sometimes carried out by States against civilians or non-combatants, these acts are, nevertheless, not regarded as terrorist acts in modern society and as such are not considered as terrorism. Notably, in recent times, when a State is associated with acts of terrorism, several terms are used to identify these acts. They are sometimes referred to as war crimes, crimes against humanity, human rights violations, genocide and atrocities. ${ }^{23}$ Therefore, the modern perspective on terrorism takes into consideration not only the nature of violence and the targets, but also the perpetrators, which must be non-State actors. According to the Chairman of the UN Counter Terrorism Committee, there is no reference to State terrorism in twelve previous international conventions on terrorism and, as such, State terrorism was not an international legal concept. He maintains that when States abuse their powers they should be judged under international conventions dealing with war crimes, international human rights law, and international humanitarian law, rather than international anti-terrorism statutes. ${ }^{24}$ Similarly, according to Kofi Anan, the use of force by States is already regulated under international law and there is therefore no need for any debate on so-called State terrorism. ${ }^{25}$

It is important to note that the argument that a State carries out terrorist acts has been often used by terrorists themselves, maintaining that there is no difference between their acts and those of the government and State, particularly during reprisal attacks by governments. This argument has also been maintained by some sympathisers of terrorists. ${ }^{26}$ Notwithstanding the position that in modern times, acts of violence carried out by a State against its civilians are not regarded as terrorism, it has been argued that considering these as acts of terrorism would actually minimise the enormity of the systematic political violence and mass killings of civilians by those exercising State power. ${ }^{27}$

\section{State Sponsors of Terrorism}

Although States are not considered, in the modern world, to carry out acts of terrorism within their borders, some States are sponsors of terrorism. When States support groups whose political violence is directed against civilians or non-combatants in a foreign country, they are considered as sponsors of terrorism. In that case, instead of carrying out terrorist acts directly, these States sponsor, aid and assist terrorists or terrorist organisations or even acquiesce in the acts of terrorist groups within and outside their borders. These States are referred to as State sponsors of terrorism and the terrorism carried out by these sponsored terrorists or sponsored organisations is referred to as State-sponsored terrorism. The leaders of these States could therefore, in modern times, be held accountable for such atrocities. This was the case with Charles Taylor, the erstwhile President of Liberia. In April 2012, Charles Taylor was found guilty of eleven charges of war crimes, including terror, murder and rape, levelled against him

22 ibid 30.

23 ibid.

24 An Address by the Secretary General of the UN at the $4453^{\text {rd }}$ meeting of the UN Security Council in 2002. See UNSC 'Addressing Security Council, Secretary-General Calls on Counter-Terrorism Committee to Develop Long-Term Strategy to Defeat Terror' (18 January 2002) Press Release SC/7276.

Michael Lind, 'The Legal Debate is Over: Terrorism is War Crime' (Financial Times, 2 May 2005) <vietamericanvets.com/Page-PointofView-TheLegalDebate.htm> accessed 15 December 2019.

26 Walter Laqueur, No End to War: Terrorism in the Twenty-first Century (Continuum 2003) 237.

27 ibid. 
at the UN-backed Special Court for Sierra Leone (SCSL) in The Hague. ${ }^{28}$ In May 2012, he was sentenced to a 50-year prison sentence. ${ }^{29}$ In its ruling, the Court held that, from 1997, Charles Taylor knew about the campaign of terror being waged against the civilian population in Sierra Leone and about the sale of 'blood diamonds' in return for weapons. ${ }^{30}$

In recent times, notable countries have been accused by the United States of America of being State sponsors of terrorism, on the grounds that they allowed the use of acts of terrorism within their borders or refused to assist in dealing with persons or organisations involved in terrorism within and outside their borders. Some of these States include Afghanistan during the Taliban regime and before the US invasion, Iran since 1984, Sudan before the eviction of Osama Bin Laden, Libya before the US invasion and deposition of Muammar Gaddafi and Iraq before the US invasion of Iraq and deposition of Saddam Hussien following the 9/11 attack. It was this issue of the State sponsorship of terrorism that made the United States of America propose the war on terror and fight it with its coalition allies against Iraq and Afghanistan, which were believed to have been State sponsors of Osama Bin Laden and Al Qaeda. Thus, the USA, alongside its allies, invaded Iraq under the allegation that Iraq was producing and stockpiling weapons of mass destruction, which could get into terrorist hands and which also represented a threat to world peace and security. It was also alleged that Iraq had ties with Bin Laden's Al Qaeda group, which masterminded the bombing of the twin towers of the American World Trade Centre on 11 September 2001. The justification offered for the invasion of Iraq was to prevent terrorism, or future attacks by Iraqi government-sponsored terrorists, against the United States of America, its allies and other nations of the world. ${ }^{31}$

In the present period, and with the global interest in the fight against terrorism, certain countries are still being listed as currently sponsoring terrorism. These countries include Iran, Syria, Libya and Sudan. ${ }^{32}$ Many other countries have recently been accused of sponsoring terrorism, either by aiding, abetting, assisting or harbouring terrorists. These include Qatar and Turkey. In the case of Iran, it has been reported that much of the terrorism in the world is orchestrated by Iran, especially those acts directed against the USA. ${ }^{33}$ In 2015 , Iran was shown to have remained the most prominent State sponsor of terrorism. ${ }^{34}$ The country has allegedly provided a wide range of support, including financial, training and equipment, to terror groups around the world. For example, Iran was shown to have provided arms and cash to terrorist groups and Shia militias in Lebanon, Syria, Iraq, Afghanistan and Yemen. ${ }^{35}$ Other

28 Jon Silverman, 'Taylor Sierra Leon War Crimes Verdict Welcomed' (BBC News, 26 April 2012) $<$ bbc.com/news/world-africa-17864387> accessed 15 December 2019.

29 Ben Brumfield, 'Charles Taylor Sentenced to 50 Years for War Crimes' (CNN News, 31 May 2012) <cnn.com/2012/05/30/world/africa/netherlands-taylor-sentencing/index.html> accessed 15 December 2019.

30 Owen Bowscott, 'War Criminal Charles Taylor to Serve 50 Years Sentence in British Prison' (The Guardian, 10 October 2013) <theguardian.com/world/2013/oct/10/former-liberian-president-charles-taylor-britishprison> accessed 15 December 2019.

31 Chris Opukri and Kimiebi Ebienfa, 'International Terrorism and Global Response: An Appraisal' (2013) 1(3) American Journal of Humanities and Social Sciences 109, 112.

32 Peter Huessy, 'Which Nation is (Still) the Number One Sponsor of Terrorism' (Gatestone Institute International Policy Council, 3 October 2016) <gatestoneinstitute.org/9041/iran-terrorism-sponsor> accessed 15 December 2019.

33 ibid.

34 ibid.

35 ibid. 
groups sponsored by Iran include Hezbollah, Hamas, the Palestinian Islamic Jihad, Houthi rebels in Yemen and Shia militias in Bahrain. ${ }^{36}$ Iran, together with other States that sponsor terrorism, provides safe havens around the world where terrorists are able to organise, plan, raise funds, communicate, recruit, train, transit and operate ${ }^{37}$ Iran had provided training and facilitated the 9/11 hijack in collaboration with Hezbollah and, since 9/11, Iran harboured senior Al Qaeda operatives and facilitated the flow of fighters and funds to Al Qaeda through Iran. ${ }^{38}$ Iran had also previously financed the attack on the Pan Am flight that blew up over Scotland in December 1988, the 1996 terror attacks against Americans at Khobar Towers in Saudi Arabia, the 1998 bombings of the American embassies in Kenya and Tanzania and the 1983 bombings of the Marine barracks and embassy in Lebanon. ${ }^{39}$ Iran has also been found guilty in US Courts for sponsoring terrorism, which resulted in the freezing of its assets in favour of the terrorists' victims. ${ }^{40}$ Especially threatening is Iran's missile and technology cooperation with North Korea, which has raised fears regarding Weapons of Mass Destructions (WMD) getting into terrorist hands. ${ }^{41}$

The involvement of Qatar and Turkey in the sponsorship of terrorism has been associated with Hamas, Al Qaeda and other terrorist groups. Hamas, which has long been designated as a terrorist organisation and treated as such by many governments, including the United Arab Emirates, Saudi Arabia and Egypt, still receives support from Qatar and Turkey. These countries are two firm allies of Hamas. Both give public and financial assistance estimated to be in the hundreds of millions of dollars to Hamas. Qatar is also known to host Hamas's political bureau, which includes Hamas leader Khaled Meshaal, who stepped down in 2017. Hamas' leader also visited the Turkish President Recep Tayyip Erdogan, who decided to break Hamas out of its political and economic seclusion. According to Erdogan, Hamas was to be seen as a political organisation rather than a terrorist one. In 2007, Qatar and Turkey were the only countries that backed Hamas when Hamas ousted the Palestinian Authority from the Gaza Strip. Between 2008 and 2009, Qatar also strengthened ties with Hamas such that Hamas $^{\prime 42}$ leader was invited to attend the Doha Summit, where Qatar pledged USD 250 million to repair the damage caused by Israel in the war on Gaza. Consequently, Israel's ${ }^{43}$ blockade was described by Qatar as unjust and immoral. This explains why Qatar has been handing out political, material and humanitarian support to Hamas. As this relationship continues at time of writing, some countries, including Saudi Arabia, Egypt, Bahrain and the

36 ibid.

37 ibid.

38 ibid.

39 ibid

40 Asa Fitch, 'Iran Sues US in International Court over Frozen Assets' (The Wall Street Journal, 16 June 2016) $<$ wsj.com/articles/iran-sues-u-s-in-international-court-over-frozen-assets-1466027629> accessed 15 December 2019.

41 ibid.

42 Jonathan Schanzer, 'How Hamas Lost the Arab Spring' (The Atlantic, 21 June 2013) $<$ theatlantic.com/international/archive/2013/06/how-hamas-lost-the-arab-spring/277102/> accessed 15 December 2019.

43 CBN News, 'Qatar Pledges Aid to Hamas-Fatah Gov't' (CBN News, 9 August 2014) $<$ cbn.com/cbnnews/israel/2017/november/qatar-pledges-aid-to-hamas-fatah-gov-t $>$ accessed 15 December 2019; Adnan Abu Amer, 'Hamas Ties to Qatar Have Cost' (Al-Monitor, 22 April 2013) <almonitor.com/pulse/fr/originals/2013/04/hamas-qatar-relationship-independence.html> accessed 15 December 2019. 
United Arab Emirates have labelled Qatar a terrorist haven, as it continues to harbour Hamas leader Meshaal, among other terrorists. Qatar also harbours Husam Badran, the spokesperson for Hamas and a former leader of the Hamas military wing in the West Bank, who instigated several deadly suicide bombings of the second intifada, including the Dolphinarium discotheque bombing in Tel Aviv, which killed 21 people. For its part, Turkey has been involved with Hamas by providing a safe haven to its members, including Saleh al-Arouri, a senior Hamas officer alleged to have orchestrated the June 2014 abduction and killing of the three Israeli teenagers and to have started the 50-day war between Israel and Palestine. AlArouri now lives in Turkey.

While Saudi Arabia has joined in accusing Qatar of supporting terrorism, its involvement in supporting terrorism must not be underestimated. Saudi Arabia is shown to be the world's largest source of funds and promoter of Salafist Jihadism, which forms the ideological basis of Al Qaeda, the Taliban, ISIS and other violent Islamic extremist groups. In 2009, the Pakistan based Lashkar-e-Taiba, which carried out the 2008 Mumbai Terrorist attack, was shown to have used a Saudi-based shell company to fund its activities in 2005. Saudi Arabia has been alleged to be the soil in which Al Qaeda and its sister terrorist organisations are flourishing. In 2016, it was maintained that Saudi Arabia had spent millions promoting Wahabism, the radical form of Sunni Islam that inspired the 9/11 hijackers and currently inflames the Islamic State. ISIS is ideologically, financially and logically supported and sponsored by Saudi Arabia, who has long been alleged to be responsible for exporting extremist Islamic ideology across its borders. Although Saudi Arabia has joined Egypt, Bahrain and the United Arab Emirates in raising serious concerns regarding Qatar's ${ }^{44}$ support for terrorism, it must be maintained that Saudi support for terrorism dwarfs Qatar's support of terrorist groups in the Islamic world. In spite of these accusations, Saudi Arabia has become a strong ally of the US in the fight against terrorism and extremism in the Middle East and beyond. ${ }^{45}$

\section{International Legal Regimes on Terrorism}

Against the exisiting backdrop, the need to prevent, suppress or eliminate State-sponsored terrorism has given rise to several treaties, conventions, protocols and resolutions by the United Nations. One example is UN Security Council Resolution $1373 .{ }^{46}$ This Resolution calls on all member States to work together to prevent and suppress terrorist acts. It reaffirmed that every State has the duty to refrain from organising, instigating, assisting or participating in terrorist acts in another State or acquiescing in organised activities within its territory directed towards the commission of such acts. ${ }^{47}$ The Resolution, made under Chapter VII of

44 Dedan Walsh, 'Wikileaks Cables Portrays Saudi Arabia as a Cash Machine for Terrorist' (The Guardian, 5 December 2012) <theguardian.com/world/2010/dec/05/wikileaks-cables-saudi-terrorist-funding> accessed 15 December 2019.

45 Bob Corker, 'Saudi Terrorism Support Dwarfs' $(A l$ Jazeera, 13 July 2017) <aljazeera.com/news/2017/07/bob-corker-saudi-support-terror-dwarfs-qatar-170713043902732.html> accessed 15 December 2019.

46 UN Security Council Resolution 1373 (28 September 2001) UN Doc S/Res/1373.

47 Phillip E Agbebaku, 'The UN and Global Coalition Against Terrorism' in Thomas A Imobighe and ANT Eguavoen (eds), Terrorism and Counter Terrorism: An African Perspective (Heinemann Educational Books Nigeria Ltd 2006) 139. 
the UN Charter, also provides that all States shall prevent and suppress the financing of terrorist acts, freeze the funds of terrorists, deny terrorists access to information and afford the greatest measure of assistance in the criminal investigations and proceedings against terrorists, amongst other provisions.

As well as this Resolution, there are several conventions and protocols that deal with terrorism. These include: the 1963 Convention on Offences and Certain Other Acts Committed on Board Aircraft; ${ }^{48}$ the Convention for the Suppression of Unlawful Seizure of Aircraft of 1970; ${ }^{49}$ the Convention for the Suppression of Unlawful Acts against the Safety of Civil Aviation of $1971,{ }^{50}$ the 1973 Convention on the Prevention and Punishment of Crimes against Internationally Protected Persons, including Diplomatic Agents.; ${ }^{51}$ the 1979 International Convention against the Taking of Hostages; ${ }^{52}$ the 1980 Convention on the Physical Protection of Nuclear Material; ${ }^{53}$ the 1988 Protocol for the Suppression of Unlawful Acts of Violence at Airports Serving International Civil Aviation; ${ }^{54}$ the 1988 Convention for the Suppression of Unlawful Acts against the Safety of Maritime Navigation; ${ }^{55}$ the Convention for the Suppression of Unlawful Acts against the Safety of Fixed Platforms located on the Continental Shelf $1988,{ }^{56}$ the 1991 Convention on the Marking of Plastic Explosives for the Purpose of Detection $;{ }^{57}$ the 1997 International Convention for the Suppression of Terrorist Bombings ${ }^{58}$ the 1999 International Convention for the Suppression of the Financing of

48 International Convention for the Suppression of Terrorist Bombings (adopted 14 September 1963, entered into force 4 December 1969) 704 UNTS 219. This convention was ratified by the Nigerian State on 7 April 1970.

49 Convention for the Suppression of Unlawful Seizure of Aircraft (adopted 14 September 1963, entered into force 4 December 1969) 860 UNTS 105.

50 Convention on the Suppression of Terrorist Bombings and on Financing (adopted 23 September 1971, entered into force 26 January 1973) 974 UNTS 177.

51 Convention on the Prevention and Punishment of Crimes against Internationally Protected Persons, including Diplomatic Agents (adopted 14 December 1973, entered into force 20 February) 1035 UNTS 167.

52 International Convention Against the Taking of Hostages (adopted 17 December 1979, entered into force 3 June 1983) 1316 UNTS 205.

53 Convention on the Physical Protection of Nuclear Material (adopted 3 March 1980, entered into force 8 February 1987) 1456 UNTS 101. This Convention was amended in 2005 by the 2005 Amendments to the Convention on the Physical Protection of Nuclear Material.

541988 Protocol for the Suppression of Unlawful Acts of Violence at Airports Serving International Civil Aviation, Supplementary to the Convention for the Suppression of Unlawful Acts Against the Safety of Civil Aviation (adopted 24 February 1988, entered into force on 6 August 1989) 1589 UNTS 474. This Convention was ratified by the Nigerian State on 25 March 2003.

55 Convention for the Suppression of Unlawful Acts against the Safety of Maritime Navigation (adopted March 1988, entered into force 1 March 1992) 1678 UNTS 221. The Nigerian State ratified the convention on 24 February 2004.

56 Convention for the Suppression of Unlawful Acts Against the Safety of Fixed Platforms Located on the Continental Shelf (adopted 10 March 1988, entered into force 1 March 1992) 1678 UNTS 374.

57 Convention on the Marking of Plastic Explosives for the Purpose of Identification (adopted 1 March 1991, entered into force on 21 June 1998) 2122 UNTS 374. This Convention was ratified by the Nigerian State on 10 May 2002

58 International Convention for the Suppression of Terrorist Bombings (adopted 15 December 1997, entered into force 23 May 2001) 2149 UNTS 256. This Convention was adopted by the Nigerian State on 24 September 2013. 
Terrorism $;{ }^{59}$ the 2005 Amendments to the Convention on the Physical Protection of Nuclear Material, ${ }^{60}$ the 2005 Protocol for the Suppression of Unlawful Acts against the Safety of Fixed Platforms Located on the Continental Shelf; ${ }^{61}$ the 2005 International Convention for the Suppression of Acts of Nuclear Terrorism ${ }^{62}$ and the 2010 Convention on the Suppression of Unlawful Acts Relating to International Civil Aviation. These treaties are the international normative framework for combating terrorism. They contain a series of legally binding standards for nation States geared towards the prevention and control of terrorism. They deal with particular acts of terrorism and place obligations or responsibilities on State parties to comply with their provisions. The principal obligation is to incorporate the crimes defined therein into the domestic criminal laws of State parties and to make these punishable by sentences that reflect the gravity of the offence. ${ }^{63}$

In compliance with the demands of these instruments, States across the world have enacted domestic legislation criminalising terrorism in their respective jurisdictions. Some States have adopted the international conventions on specific acts of terrorism as agreed and made them part of their domestic laws. Others have referred to these conventions in their domestic legislation, thereby making them part of their law. Unfortunately, many States, some of which are parties to many treaties on terrorism, have failed to ensure the enforcement of these laws within and outside their jurisdictions. This failure is partly associated with their involvement in the mobilisation of resources for terrorist groups.

\section{Mobilising Resources for Terrorists Groups}

The mobilisation of resources for terrorist purposes, or the making available of resources for terrorist groups, has been stated by scholars to be one of the causes of, or an explanation for the existence of, terrorism in the world. This is rooted in the Resource Mobilisation Theory of Terrorism. According to this theory, what gives rise to terrorism is the ability of terrorists to access certain resources, without which violent attacks cannot be carried out. McCarthy and Zald, together with McAdam, maintain that the probability of the emergence of any social protest movement depends not only on the opportunities offered by the relevant social situation, but also on the capability of the movement to mobilise certain basic resources ${ }^{64}$ This is so because, specifically, a terrorist campaign requires materials (including money, weapons, political space and technology), people (militants, collaborators, supporters and sponsors) and symbols (clearly linked to the ideologies that motivate terrorists to commit terrorist acts). Material is required by terrorists to finance their dastardly activities. The amount of money

59 International Convention for the Suppression of the Financing of Terrorism (adopted 9 December 1999, entered into force 10 April 2002) 2178 UNTS. The Nigerian State signed this Convention on 1 June 2000 and it was ratified by the Nigerian State on 16 June 2003.

60 Amendment to the Convention on the Physical Protection of Nuclear Material (adopted 8 July 2005, entered into force 8 May 2016) INFCIRC/274/Ref.1/Mode.1.

612005 Protocol to the 1988 Convention for the Suppression of Unlawful Acts against the Safety of Fixed Platforms Located on the Continental Shelf (adopted 14 October 2005, entered into force 28 July 2010) 1678 UNTS I-29004. As of February 2016 it had been ratified by 36 States.

62 International Convention for the Suppression of Acts of Nuclear Terrorism (adopted 13 April 2005, entered into force 25 October 2012) 2445 UNTS 89. This Convention was ratified by the Nigerian State on 25 September 2015.

63 International Convention for the Suppression of Financing of Terrorism (n 64) art 4.

64 Luis de la Corte, 'Explaining Terrorism: A Psychosocial Approach' (2007) (1)(2) Perspective on Terrorism 1, 5. 
involved is usually huge and is often provided by organisations, individuals and State entities sometimes in the form of donations. Despite the existence of legal setups prohibiting financial transactions for the sponsorship of terrorism, some of these financial provisions are made transferable to terrorist groups through financial institutions, non-financial institutions and individuals with State support amidst high, but secret, technological competence. The weapons needed for terrorism are also usually massive. They are transported into target States, particularly through land borders and seaports, despite the prohibitions of relevant international legal regimes and domestic legislation. The political space that is conducive for the accumulation of weapons, training of terrorist fighters and accommodation of terrorist leaders is also required to hatch and carry out acts of terrorism. People are also required to carry out terrorist acts. Fighters are required to be recruited and trained. Coordinators are also required to be recruited and trained. Collaborators, sponsors and supporters are required in order to facilitate the activities of the terrorists from one point to another. They could be in the target States or neighbouring States, but they are key instruments in the planning and execution of acts of terrorism. They provide money, weapons, training facilities and a safe haven for terrorists. Symbols that clearly link terrorists to the ideology that motivates them are also required for acts of terrorism to be carried out. The ideology could be founded on religion, ethnicity or tradition. It is this ideology that motivates the terrorists and drives them to carry out atrocities against innocent civilians in their quest to achieve their goals. According to this theory, these are the resources required for any terrorist campaign, without which terrorism cannot occur. This position is strongly held by Waldman. ${ }^{65}$

Notably, a greater part of terrorists' time and effort is dedicated to obtaining the above resources. Bovenkerk and Chakra both agree that, in order to obtain these primary resources, terrorists may engage in activities such as theft, extortion, robbery, human trafficking, gunrunning, kidnapping or various legal and illegal businesses. ${ }^{66}$ These criminal activities, which are usually carried out to mobilise resources for terrorism, often enjoy a smooth sail in a country where security is porous and/or in a failed State. Aside from engaging in these activities, many terrorist organisations have support from States that are sympathetic to the course of the terrorists or are otherwise interested in the political balance favourable to them. Accordingly, since an open confrontation would impugn on the sovereignty of the target State, these States clandestinely provide the required material supports for terrorist groups, including the training of members used in carrying out terrorist attacks on the target States. These issues have been raised by many target States, who continuously accuse the supporting States of sponsoring terrorism in their countries. This has been done several times by India, which has accused Pakistan of giving support to Lashkar-e-Taiba (LeT), who have perpetrated terrorism in India. ${ }^{67}$ Pakistan is shown to use various terrorist groups as proxies but vehemently denies involvement with these groups, and avoids establishing a connection that would serve as evidence of a relationship. ${ }^{68}$

65 ibid.

66 Frank Bovenkerk and Bashir Abou Chakra, 'Terrorism and Organized Crime' (2004) 1(2) UN Forum on Crime and Society 3.

67 Prem Mahadevan, 'India and Global Discourse on State-sponsored Terrorism' (2017) 2(3) Rising Power Quarterly 185, 187.

68 Nathaniel F Manni, 'Iran's Proxies: State Sponsored Terrorism in the Middle East' (2012) 3(3) Global Security Studies 34 . 
Accusations have been made against numerous States regarding their roles in the provision of resources to alleged terrorist groups. These States include the US, which has been at the forefront of the global campaign against terrorism amidst accusations that their hands, too, are unclean. Iran is one of the States consistently labelled by the US as a State sponsor of terrorism. Several terrorist groups in the world identified as being sponsored by Iran include, Hamas, Palestinian Islamic Jihad (PIJ), Hezbollah and Al Qaeda. ${ }^{69}$ Similarly, Qatar has recently been accused by the gulf States of Saudi Arabia, United Arab Emirates (UAE), Bahrain and Egypt for supporting terrorist groups in the region. Amid accusations and counter-accusations of State sponsorship of terrorist groups, not much has been done by the world community to address the involvements of States in funding terrorism. Collective military efforts by the world community against States accused of the sponsorship of terrorism have never been undertaken and investigative reports of such allegations have scarcely been implemented against involved States. The imposition of sanctions against States identified as sponsors of terrorism has, until recently, been limited to sanctions imposed by the US. This has led to the international community not being taken seriously by some States, which continue to fund and allow terrorist groups to use their territories for the recruitment, training, arming and planning of terrorist attacks on target States. Thus, the availability of both human and material resources in perpetrating terrorism better explains the rise and continued existence of terrorists and terrorist organisations in many countries today, with continuing attacks on soft targets. Until drastic measures are taken, this trend will persist.

\section{The Way Forward}

With States participating in terrorism by way of sponsorship, the fight to end terrorism has become more complex. For effective action to deal with State sponsorship of terrorism, international laws on terrorism must be strengthened. The definitional disagreement must be resolved in order to bring all States at parity regarding what constitutes terrorism. This is in light of the collective need to condemn its use and ultimately bring about a resolve to punish the perpetrators, as well as the sponsors, of terrorism. This will assist in the establishment of a law that will be universally applicable in dealing with terrorism and the sponsors thereof across the globe. This legal instrument should be made to reflect existing international legal instruments on terrorism, in order to ensure compatibility, ease enforceability and avoid inconsistencies or contradictions. Particular attention must be given to the enforcement of the 1999 International Convention against Terrorist Financing and other related conventions. State parties must ensure the enforceability of these conventions. It is now time that international agreements be given a new nature. Accordingly, punitive measures must be incorporated into these agreements in order to ensure compliance and avoid defiance. In so doing, State sponsors would halt their continuous involvement in providing supports to terrorist groups.

Increasing diplomatic relations to expose and deal with terrorist-supporting States and reducing the interference by those States in the activities of other countries constitute two of the measures needed to address the problem of State sponsorship of terrorism. The UN must be fully and consistently involved in the affairs of States which currently support terrorism or host proxies from terrorist-supporting States. Relying on good diplomacy and incentives, the

69 ibid. 
superpowers and their allies should take stronger action against States that host terrorist groups and their proxies within their borders. This will limit the ability of terrorist-supporting States to influence the politics of weak States, and make them recognise that the time has come to comply with international legal regimes. The collective actions of UN member States, leading the neutralisation of ISIS in Syria and Iraq, show the power of multilateral pressures and diplomacy. This combination of international pressure and good diplomacy, if applied on a continuous and sustained basis, would stem the tide of State sponsorship of terrorism. Moreover, military actions as a strong response should be used by target States against terrorist targets in other countries and those countries' base of support for the terrorists. Thus, States should take strong measures against other States that sponsor terrorism. ${ }^{70}$ The US, for instance, is fully within its rights to conduct a proportional military response against suitable, identifiable, and involved targets in Iran or any other country identified with the sponsorship, in any form, of acts of terror in the US. This response will in many ways be considered similar to the military operations carried out against Al Qaeda in Pakistan and those against Iraq. The Iranian government has, through the Iran Quds Force, carried out acts of terrorism and provided material support to the Taliban and other terrorist groups. The Tehran government must be restrained and held responsible for the conducts of the Quds Force.

The imposition and enforcement of strong sanctions against supporting States remains a significant measure commonly used against States associated with terrorism. Accordingly, for progress to be made in this regard, a number of sources of State sponsored terrorism in the world, like Iran, must be shut down. ${ }^{71}$ This could be done in many ways, for example: economic sanctions on such States, their allies and countries doing business with them, which includes a ban all foreign investment, loans, credits, subsidised trade and refined petroleum exports; denial of aid to such States or the withdrawal of such aid where it was provided previously and use of tough immigration laws against their citizens, particularly top government functionaries and business moguls, which includes denial of visas and restrictions on information gathering and sharing, particularly information on security. These sanctions must be strictly enforced. The enforcement of imposed sanctions should be made collectively by UN member States so that affected countries will have no leeway but to abandon their support of terrorist groups. A situation where one country imposes sanctions on another, yet other countries maintain business ties with that country, weakens this measure. For instance, although the US has imposed several sanctions on Iran in recent times, Russia, China and some members of the European Union are still doing business with Iran. ${ }^{72}$ This situation has weakened the imposition of sanctions against State sponsors of terrorism from achieving the desired goal. To forestall this, the world's superpowers must agree, through the UN, to take concrete, significant and decisive action against Iran and any other State supporting terrorism, with the intention to curb their support for terrorists and their networks. The plight of civilians in States affected by terrorism should take precedence over the political and economic interests of the superpowers. Sanctions imposed by the UN with the unequivocal approval of the

70 James Jay Carafano, 'Forty-Second Plot Highlights State-Sponsored Terrorism Threat' (The Heritage Foundation, 12 October 2011) <report.heritage.org/wm3392> accessed 15 December 2019.

71 Huessy (n 32).

72 Anjli Raaval and others, 'China defies US sanctions by Tapping Iran Oil Supplies' (Financial Times, 27 June 2019) <ft.com/content/6b944786-9809-11e9-8cfb-30c211dcd229 > accessed 15 December 2019. 
superpowers will most likely prove more effective than those of the past, which Iran was able to circumvent with the support of these superpowers.

Increasing diplomatic relations to expose involved States should also be used in dealing with State sponsorship of terrorism. Public diplomacy should be increasingly used in order to expose the States involved in the sponsorship of terrorism. Such a campaign should document the involvements of State sponsors, specific aids and assistance, the quandaries of victims, the number of recorded fatalities and the hopelessness felt by surviving citizens displaced from their homes. The UN should provide a permanent platform for individuals and States to broadcast the activities of those States involved in the sponsorship of terrorism, in order to expose them.

Increasing assistance to failed States and decreasing assistance to involved States is yet another measure that should be used against State sponsorship of terrorism. Failed States have been identified as safe havens for terrorists. It is here that terrorists remain, recruit, train and plan for the execution of terrorist violence. Mobilisation of resources securely takes place in safe havens where supplies are unhindered and sometimes undetected. In order to prevent such States from becoming hotbeds for the planning of acts of terrorism, UN member States should relentlessly assist them. This will deter States that sponsor terrorism from using such States as a conduit for their acts supporting terrorist violence. Furthermore, any assistance provided for States identified as sponsors of terrorism should be completely withdrawn. This will warn such States and force them to change their policies. These measures, which are in line with UN Resolutions to counter the threats of terrorism, are identifiable measures that could deter States from supporting terrorists across the world. ${ }^{73}$

\section{Conclusion}

Many countries have expended enormous resources in dealing with terrorism. The international community has done much to ensure that terrorist violence across the world is thrown into the abyss of history. However, the more the war against terrorism is taken to the terrorists, the more terrorist violence continues amidst support provided by certain States. This State sponsorship has remained a significant impediment to the global fight against terrorism. Accordingly, cutting off State support for terrorists remains the sine qua non for achieving success in the global war against terror.

$*$

www.grojil.org

73 Agbebaku (no 52) 140. 